\title{
FINANCIAL PERFORMANCE OF CZECH SUGAR REFINERIES: CASE STUDY TESTING THE POST-CRISIS PERIOD 2010-2013
}

\author{
Jiří Strouhal \\ Škoda Auto University Mladá Boleslav, Czech Republic \\ Petra Štamfestová \\ University of Economics Prague, Czech Republic
}

\begin{abstract}
The main purpose of this paper is to evaluate and compare a financial performance of Czech sugar refineries within a period 2010-2013. Due to the availability of financial statements for the requested periods were analysed following public limited companies - Cukrovar Vrbátky, Tereos TTD, Litovelská cukrovarna and Moravskoslezské cukrovary. There is an applied standard financial analytical approach, i.e. there are performed ratio analysis and tested selected bankruptcy and credibility indexes for financial performance analysis. The results of this analysis point out the stability of this industry having as its leaders Cukrovar Vrbátky and Moravskoslezské cukrovary.
\end{abstract}

Keywords: sugar industry, financial performance, ratio analysis, bankruptcy and credibility indicators

JEL code: G30

\section{Introduction}

The financial performance of business corporations and their financing are very attractive not only from the perspective of practical users, but also from the research point of view. Andrews (1980) examined the corporate financing in relation to the corporate strategy with the purpose to identify strengths and weaknesses of the companies.

Financial management is a key factor for strategic financing, restructuring or expansion of business activities. Its major goal is not only to maximize profit, but also the shareholders' value. Therefore, business corporations need additional financial sources to be able to implement an internal growth strategy (Storey, 1985). Hitt and Ireland (1985) in their research pointed out that the financial activities of business corporations are positively linked to their financial performance.

To analyze corporate performance there is necessary to obtain relevant financial data from financial statements, however, many of the Czech companies are not too willing to publish these on time, obviously because of the sensitivity of data and vague deadline specified within the current legislature. According to the Czech Act on Accounting, companies are obliged to publicly present their financial statements within 30 days after its approval by the general assembly, but not later than one year after the year-end.

The accounting data are from time to time also criticized as barely reliable and very subjective given by the tendency of some managers to apply creative accounting (Dess and Robinson, 1984; Sapienza et al., 1988; Powell and Dent-Micallef, 1997). The major problem in the Czech Republic is how to reliably set up fair values of certain assets due to the lack of transparency of Czech markets.

Due to this fact there became very popular KPIs (key performance indicators) as well as other strategically-oriented scales (Dess and Robinson, 1984; Robinson and Perce, 1988; Venkatraman and Ramanujam, 1986; Spanos and Lioukas, 2001; Lawrence and Lorsh, 1967; Dess, 1987; Powell, 1992; Powell and Dent-Micallef, 1997). 


\section{Methodology}

As a data source were used publicly available financial statements of Czech sugar refineries for the period 2010-2013 retrieved from the Czech business register. The statements were restructured for the purposes of financial statements analysis. For the assessment of financial performance there are applied standard methods of financial analysis, specifically the analysis based on financial ratios and selected credibility and bankruptcy models. For the analysis of profitability there was analyzed ROA, ROE and ROS, for the verification of liquidity current ratio, quick ratio and cash ratio, and for the purposes of the debt position analysis trade deficit being a difference between receivables collection period and payables settlement period, and debt ratio itself. The computation of these ratios was based on standard methodology (e.g. Brealey et al., 2013; Altman, 1968). Financial analysis assesses whether and how to achieve the main corporate goals in any given year, assesses its financial performance, being a basis for comparison with competing firms or with desirable, generally accepted values of individual designed ratios between the items of the financial statements.

\section{Results}

If we look back on the development of profitability, there could be seen in all analyzed companies relatively significant fall down in 2012 for each of the profitability ratios. At TTD Tereos the most significant factor was the decline in sales for 49 per cents compared to previous accounting period. The main reason was decline in customers demand and not the price level as the average price increased from $15.48 \mathrm{CZK} / \mathrm{kg}$ in 2011 to $19.08 \mathrm{CZK} / \mathrm{kg}$ in 2012. Production power declined from $25.56 \%$ in 2011 to $11.04 \%$ in 202. The return of assets slightly increased in 2013 thanks to higher sales (the average price of sugar decreased in 2013 on $18.29 \mathrm{CZK} / \mathrm{kg}$ ) and slight change in the capital structure on the value of $14.38 \%$.

As for the profitability for the owners, development basically copied the production power, highest values reached in 2011, 28.29\% when in 2012, followed by a drop of 15.13 percentage points. Most significant factor behind this drop was decrease in assets turnover and the decrease in return on sales. The effect of changing assets turnover from 1.25 to 0.56 between 2011 and 2012, without affecting the other indicators would have caused the drop in ROE for 15.91 percentage points, as well as the effect of changes in return on sales from $16.38 \%$ on $14.29 \%$ between the years 2011 and 2012 without the influence of other indicators would have caused the drop in ROE for 2.84 percentage points. However, thanks to the positive impact of financial leverage was the overall impact on the ROE less than the sum of the previous influences of change of the indicator of financial leverage value in 2011 to 1.38 value 1.64 in 2012, caused the increase in ROE without affecting the other indicators on 3.61 percentage points. In the last analyzed period was recorded increase in ROE of 5.38 percentage points to $18.53 \%$. This change was positively affected by the assets turnover, which rose to a value of 0.86 and without the influence of other indicators caused the increase in ROE for 6.79 percentage points. However, profit margin and financial leverage had negative impact on ROE, where the decline in profit margins compared to the year 2012 by 0.95 percentage points caused the decline in ROE about 1.1 percentage points and the decline in the financial leverage caused the decline in ROE by 0.03 .

Other, equally important areas of financial performance analysis, is the assessment of the ability to pay. Liquidity in all three of its stages of company Tereos TTD was after the whole analyzed period more less good. The current ratio reached the average value of 1.6, which is at the lower limit of the recommended interval for the manufacturing companies. Quick ratio reaches a nice average value of 0.8 , while in the last two years, holding on to the value of 0.6 , which could be considered as acceptable. Cash ratio recorded throughout the examined period the largest fluctuations, when in the year 2010 declined to very low values of 0.06, despite 
next year slightly increased to an acceptable value of 0.38 . This shift occurred primarily due to the possession of a higher cash balance, current liabilities remained stable. There shall be however stated that in the next period the cash balance again dropped down to the same level as of 2010 and current liabilities doubled compared to 2012. That is why the cash liquidity achieved the critical value of 0.03 . In 2013 cash balance raised five times and despite of the slight increase in current liabilities, cash ratio gained an acceptable value of 0.15 .

The trade deficit of Tereos TTD is in all analyzed years negative, which is a desirable output, but in recent years, mainly due to negative developments in terms of due dates of current liabilities shows declining trend. The payables settlement period decreased from 211.2 days in 2012 to 131.5 days in 2013. The development in receivables collection period can be evaluated as a positive one as this indicator declined from 101.1 days in 2012 to 63.8 days in 2013.

Debt position of the company fluctuates about the average of $33 \%$, which is not very much and there might be considered a higher involvement of debt capital because of the positive financial leverage effects. Currently is Tereos TTD overcapitalized and equity financing is unnecessarily expensive for the company. There shall be also pointed out on the structure of liabilities when a working capital is financed by equity as well as non-current liabilities.

Second analyzed company is Moravskoslezské cukrovary. This corporation realized also a decrease in profitability in 2012 like other sugar refineries, however this decrease was much smoother for about 7 percentage points, however in 2013 ROA declined for 38 percentage points on $14.23 \%$ due to the EBIT lower for 34 percentage points. The profitability for the owners (ROE) was the highest one in 2011, concretely $30.65 \%$. This result was followed by a light decline for 4.74 percentage points in 2012, which was mostly affected by profit margin and by financial leverage. The impact of the change in profit margin from $19.21 \%$ to $14.65 \%$ between years 2011 and 2012 (without the impact of any other indicators) and the change in financial leverage from 1.57 on 1.38 between 2011 and 2012 would cause a decrease in ROE for 3.59 percentage points. The total impact was lower thanks to the positive impact of assets turnover raising from 1.02 in 2011 to 1.28 in 2012 causing the positive change in ROE for 6.56 percentage points. The decrease in ROE continued even in 2013 for 9.54 percentage points. There was visible a positive impact of financial leverage increasing on 1.39 and causing (without the impact of other indicators) the increase in ROE for 0.03 percentage points. Negative effect was visible in profit margin and assets turnover - profit margin decreased for 3.67 percentage points causing the decrease in ROE for 5.991 percentage points, and decrease in asset turnover for 0.2 caused the decrease in ROE for 3.58 percentage points.

The liquidity of Moravskoslezské cukrovary is in all respected ratios on a very high level what has negative effect on corporate profitability. From this perspective there shall be strongly recommended to decrease the working capital or change the structure of financing what may even cause the decrease in overcapitalisation, cheaper financial sources etc. Current ratio reaches in all respected periods the level around 3.5, quick ratio around 1.8 and cash ratio around 1.1. In the year 2013 are all these ratios even much higher than presented average values.

Company has a negative trade deficit within the whole analyzed period what is very advantageous for Moravskoslezské cukrovary, however the payables settlement period is decreasing. In the years 2010 and 2011 this period was between 60 to 68 days, in 201229 days and in 201316 days only. The reasoning is the lower bargaining power compared to Tereos TTD group because of the size and the position in the sugar refineries market. 
Moravskoslezské cukrovary report very low level of debt position - the average value was 28 $\%$ and this company uses interest-free debts only. Company has a large volume of retained earnings and therefore is also overcapitalized. From this perspective there is strongly recommended to share the profit in the form of dividends. This will lead to lower level of overcapitalization and more optimal capital structure.

The production power of the third analyzed company Cukrovar Vrbátky was highest in 2011 gaining the result of $20.86 \%$ causing the increase for 11.9 percentage points compared to 2010. In 2012 was recorded a decrease on $13.95 \%$ followed be light shift in 2013 for 14.45 $\%$. The ROE reached also its highest value of $22.8 \%$ in 2011 followed by the drop of 7.99 percentage points in the next period. The most significant reason of this change was a decrease in profit margin and financial leverage. The impact of the change in profit margin from $21.83 \%$ to $12.89 \%$ between years 2011 and 2012 (without the influence of other indicators) caused the decrease in ROE for 9.81 percentage points. The impact of the change in financial leverage from 1.35 to 1.31 caused the decrease in ROE for 0.62 percentage points. Due to the positive impact of the asset turnover was the total impact on ROE lower than the cumulative total of previous influences, since asset turnover raised from 0.77 in 2011 to 0.88 in 2012 causing the increase in ROE for 2.44 percentage points. In 2013 was ROE slightly higher for 0.5 percentage point. This was affected by the increase in profit margin for 2.86 percentage points causing the increase in ROE for 3.04 percentage points. The impact of asset turnover and financial leverage shall be, however, considered as negative one. The decrease in asset turnover from 0.88 in 2012 to 0.75 in 2013 caused the decrease in ROE for 2.5 percentage points, decrease in financial leverage for 0.001 caused the decrease in ROE for 0.01 percentage points.

The liquidity of Cukrovar Vrbátky can be considered as a higher one, however its values are lower compared to Moravskoslezské cukrovary. The average value of current ratio was 2.7 (in 2013 gains the maximum of 3.1). The quick ratio has an average value of 1.79, despite the newest data from 2013 is 1.54 . Cash ratio is considered as very high gaining an average of 1.16 .

The average trade deficit is 42.1 days what shall be considered as vital for corporate financing. Only in 2012 due to the higher volume of receivables was trade deficit lower 19.66 days. The debt position of Cukrovar Vrbátky is more less constant with the average of $25.94 \%$. We have to recommend the change in financial strategy and use more debt financing. This would have a positive impact on financial leverage and this may cause an increase in the profitability for the owners.

Litovelská cukrovarna gained an average production power of $17.29 \%$ having the highest value in 2011 of $26.27 \%$. This result was followed by the decrease for 6.32 percentage points due to the significant change in capital structure, debt financing and increase in costs of production. In 2013 continued the decrease on the value of $6.52 \%$ having the very same influences like in previous year. The ROE has the average value of $38.9 \%$ and in all analysed period Litovelská cukrovarna was the leader in this measure compared to other sugar refineries. In 2010 there was reached the result of $21.75 \%$ followed by the increase for 7.79 percentage points because of the increase of profit margin in 2011. The change in profit margin from $13.08 \%$ to $21.82 \%$ caused (without the impact of other indicators) the increase in ROE for 13.17 percentage points. The change in asset turnover from 0.98 to 0.97 caused the decrease in ROE for 0.36 percentage points and the change in financial leverage from 1.7 to 1.4 (because of the increased retained earnings) caused the decrease in ROE for 5.03 percentage points. In 2012 ROE reached very high value of $77.11 \%$ because of the significant change in capital structure. The change in financial leverage on 4.85 caused the increase in 
ROE for 64.26 percentage points. The increase in assets utility caused that asset turnover gain the value of 1.08 and have positive effect on ROE for 6.33 percentage points. There was however reported a decrease in profit margin for 7.12 percentage points because of the higher costs and this caused the decrease in ROE for 23.01 percentage points. The very same trend in profit margin was visible in 2013 with the decrease of 12.04 percentage points having a negative effect on ROE for 93.09 percentage point. This significant fall was eliminated by the increase in financial leverage on 9.43 increasing the ROE for 43.04 percentage points. The effect of asset turnover was insignificant and caused the increase in ROE for 0.15 percentage points.

The current ratio of Litovelská cukrovarna reached in average 1.95 what shall be recognized as a standard result. The highest value was reached in 2011 (2.89) because of higher working capital in respective period. In 2012 ratio declined because of the increase in current liabilities for $70 \%$ and the ratio was 1.84 . The current ratio in 2013 was 1.24 what could be considered as a critical information and it is not suitable to decrease in future years. From this point of view company has to change the strategy of working capital management. Quick ratio gained the average result of 1.15 with the highest value in 2011 caused by an increase in receivables. In last two analyzed years the values of this ratio gained results of 0.96 and 0.68 . Very critical are the results of cash ratio because of the minimalistic and insignificant share of short-term financial assets. The values of cash ratio were 0.02 in 2012 and 0.01 in 2013.

The trade deficit was also negative reaching the average value of 149.89 days. There was visible a swinging of results from 150 days in 2010 to 12 days in 2011, 39 days in 2012 and 109.62 days in 2013. Years 2011 and 2012 were mostly affected by larger volume of receivables.

The debt position of Litovelská cukrovarna is very high compared to other analyzed companies. In 2013 the debt ratio reached a critical value of $89.4 \%$. In this situation there is visible the negative effect of financial leverage. Years 2010 and 2011 were affected by different financial strategy when company cumulated its earnings and the debt ratio reached values of $41.08 \%$ in 2010 and $28.61 \%$ in 2011 . The above presented change in capital structure caused the increase in the debt ratio for $79.38 \%$.

For the evaluation of the bankruptcy position of the companies there were used the following indicators: Altman model (USA), Taffler model (UK) and index IN05 (Czech Republic). Based on the results of the Taffler model all analyzed companies reached the good financial health level within the tested period. This model didn't detect any significant problems in terms of profitability, working capital, financial risk or indebtedness. According to the Altman model Tereos TTD and Litovelská cukrovarna reached the area of grey zone with the excemption of the year 2011. For Tereos TTD the major reasons were the lower production power, lower asset turnover and higher $\mathrm{D} / \mathrm{E}$ ratio. For Litovelská cukrovarna the major reasons were also the lower production power and high debt position, but also low net working capital to assets and very high payout ratio. According to index IN05 all analyzed companies did created the value with the exemption of Tereos TTD and Litovelská cukrovarna reaching the grey zone. The last mentioned company was in 2013 even the candidate for possible bankruptcy based on IN05 indicator.

For the evaluation of the credibility of analyzed companies there were used the following indicators: credibility index (Germany), Grünwald index (Czech Republic) and Quick test (Austria). Based on the credibility index all companies do have very same rating. In 2011 reached the result of good financial health, in 2012 and 2013 was recorded a light worsening of financial health for Moravskoslezské cukrovary and Litovelská cukrovarna. From the credibility point of view the Litovelská cukrovarna gained the worst results because of its 
negative cash flows, higher debt position and lower profitability. The results of Grünwald index are in line with the credibility index in first and last year of the analyzed period. The leading company was for the years 2011 and 2012 Litovelská cukrovarna gaining the last position in 2013. Moravskoslezské cukrovary and Cukrovar Vrbátky kept the very same position of strong financial health, in 2012 there was visible the improvement of financial health for Tereos TTD having worse profitability and liquidity in previous years. Based on Kralicek's Quick test ratio the results of the companies belong to grey zone with the exemption of Moravskoslezské cukrovary having good financial health.

\section{Conclusive Remarks}

Based on the presented analysis, we can say that Czech sugar industry is basically stabilized, despite of the recent financial crisis. The most significant decline was visible for Tereos TTD group between the years 2011 and 2012 and the Litovelská cukrovarna in 2012 and 2013.

Moravskoslezské cukrovary and Cukrovar Vrbátky achieved very good results in the tested periods, they could even afford a higher level of indebtedness. Bankruptcy and credibility models prove their financial health in all consecutive years.

Companies Tereos TTD and Litovelská cukrovarna are located in the grey zone of bankruptcy and credibility models. These companies have in recent years certain problems with liquidity, despite their net working capital achieved always the positive values. In addition, the Litovelská cukrovarna is affected by the very high debt level in the last two analyzed periods. In addition, this debt has long-term nature.

\section{Literature}

Altman, E.I. (1968). Financial Ratios, Discriminant Analysis and the Prediction of Corporate Bankruptcy. Journal of Finance, no. 23, pp. 589-609.

Andrews, K. R. (1980). The Concept of Corporate Strategy. Homewood: Richard D. Irwin.

Brealey, R., Myers, S., Allen, F. (2013). Principles of Corporate Finance. Homewood: McGraw-Hill/Irwin.

Dess, G. (1987). Consensus in the strategy formulation and organizational performance: Competitions in a fragmented industry. Strategic Management Journal, vol. 8, no. 3, pp. 259277.

Dess, G., Robinson Jr., R. B. (1984). Measuring organizational performance in the absence of objective measures: The case of the privately-held firm and conglomerates business unit. Strategic Management Journal, vol. 5, no. 3, pp. 265-273.

Hitt, M. A., Ireland, R. D. (1985). Corporate distinctive competence, strategy, industry and performance. Strategic Management Journal, vol. 6, no. 3, pp. 273-293.

Lawrence, P., Lorsch, J. (1967). Organization and Environment: Managing Differentiation and Integration. Homewood: Richard D. Irwin.

Powell, T. C. (1992). Organizational alignment as competitive advantage. Strategic Management Journal, vol. 13, no. 2, pp. 119-134.

Powel, T. C., Dent-Micallef, A. (1997). Information technology as competitive advantage: The role of human, business, and technology resources. Strategic Management Journal, vol. 18 , no. 5, pp. 375-405.

Robinson, R., Pearce, J. (1988). Planned patterns of strategic behaviour and their relationship to business unit performance. Strategic Management Journal, vol. 9, no. 1, pp. 43-60. 
Sapienza, H. J.; Smith, K. G., Gannon, M. J. (1988). Using subjective evaluations of organizational performance in small business research. American Journal of Small Business, vol. 12 , no. 3, pp. 45-53.

Spanos, Y. E., Lioukas, S. (2001). An examination into the causal logic or rent generation: Contrasting Porter's competitive strategy framework and the resource-based perspective. Strategic Management Journal, vol. 22, no. 10, pp. 907-934.

Storey, D. J. (1985). Problems facing new firms. Journal of Management Studies, vol. 22, no. 3, pp. 327-345.

Venkatraman, N., Ramanujam, V. (1986). Measurement of business performance in strategy research: A comparison of approaches. Academy of Management Review, vol. 11, no. 4, pp. 801-814. 
Appendix 1: Summary of Key Indicators

\begin{tabular}{|c|c|c|c|c|c|}
\hline & & 2010 & 2011 & 2012 & 2013 \\
\hline \multirow{9}{*}{ 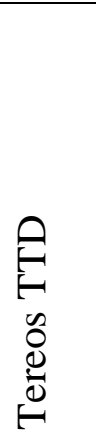 } & ROA (\%) & 17.6 & 25.56 & 11.04 & 14.38 \\
\hline & ROE (\%) & 19.44 & 28.29 & 13.16 & 18.53 \\
\hline & ROS (\%) & 13.12 & 16.38 & 14.29 & 13.34 \\
\hline & Current ratio & 1.27 & 1.87 & 1.61 & 1.63 \\
\hline & Quick ratio & 0.78 & 1.28 & 0.56 & 0.63 \\
\hline & Cash ratio & 0.06 & 0.38 & 0.03 & 0.15 \\
\hline & Receivables collection period & $\mathrm{X}$ & 44 & 101 & 64 \\
\hline & Payables settlement period & 79 & 56 & 211 & 132 \\
\hline & Debt ratio $(\%)$ & 28.6 & 27.63 & 39.01 & 37.79 \\
\hline \multirow{9}{*}{ 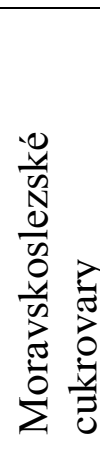 } & ROA (\%) & 10.95 & 24.62 & 22.9 & 14.23 \\
\hline & ROE (\%) & 10.74 & 30.65 & 25.91 & 16.37 \\
\hline & ROS (\%) & 7.97 & 19.21 & 14.65 & 10.97 \\
\hline & Current ratio & 4.35 & 2.66 & 3.23 & 3.84 \\
\hline & Quick ratio & 1.92 & 1.25 & 1.71 & 2.4 \\
\hline & Cash ratio & 1.13 & 0.71 & 1.17 & 1.46 \\
\hline & Receivables collection period & $\mathrm{x}$ & 46 & 43 & 54 \\
\hline & Payables settlement period & 60 & 114 & 72 & 70 \\
\hline & Debt ratio $(\%)$ & 21.54 & 36.33 & 27.79 & 27.9 \\
\hline \multirow{9}{*}{ 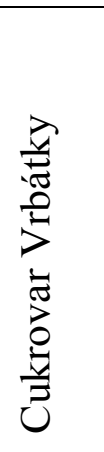 } & ROA (\%) & 8.96 & 20.86 & 13.95 & 14.45 \\
\hline & ROE (\%) & 9.42 & 22.8 & 14.81 & 15.34 \\
\hline & ROS (\%) & 9.61 & 21.83 & 12.89 & 15.75 \\
\hline & Current ratio & 2.12 & 2.73 & 3.08 & 2.71 \\
\hline & Quick ratio & 1.54 & 2.02 & 20.6 & 1.54 \\
\hline & Cash ratio & 1.15 & 1.15 & 1.43 & 0.91 \\
\hline & Receivables collection period & $\mathrm{x}$ & 72 & 71 & 64 \\
\hline & Payables settlement period & 157 & 114 & 90 & 106 \\
\hline & Debt ratio $(\%)$ & 31.12 & 25.87 & 23.42 & 23.35 \\
\hline \multirow{9}{*}{ 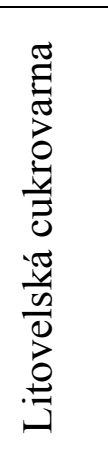 } & $\mathrm{ROA}(\%)$ & 16.4 & 26.27 & 19.95 & 6.52 \\
\hline & ROE (\%) & 21.75 & 29.53 & 77.11 & 27.2 \\
\hline & ROS (\%) & 13.08 & 21.82 & 14.7 & 2.66 \\
\hline & Current ratio & 1.83 & 2.89 & 1.84 & 1.24 \\
\hline & Quick ratio & 1.22 & 1.75 & 0.96 & 0.68 \\
\hline & Cash ratio & 0.44 & 0.69 & 0.02 & 0.01 \\
\hline & Receivables collection period & $\mathrm{x}$ & 90 & 99 & 109 \\
\hline & Payables settlement period & 147 & 102 & 137 & 219 \\
\hline & Debt ratio $(\%)$ & 41.08 & 28.61 & 79.38 & 89.4 \\
\hline
\end{tabular}


Appendix 2: Models

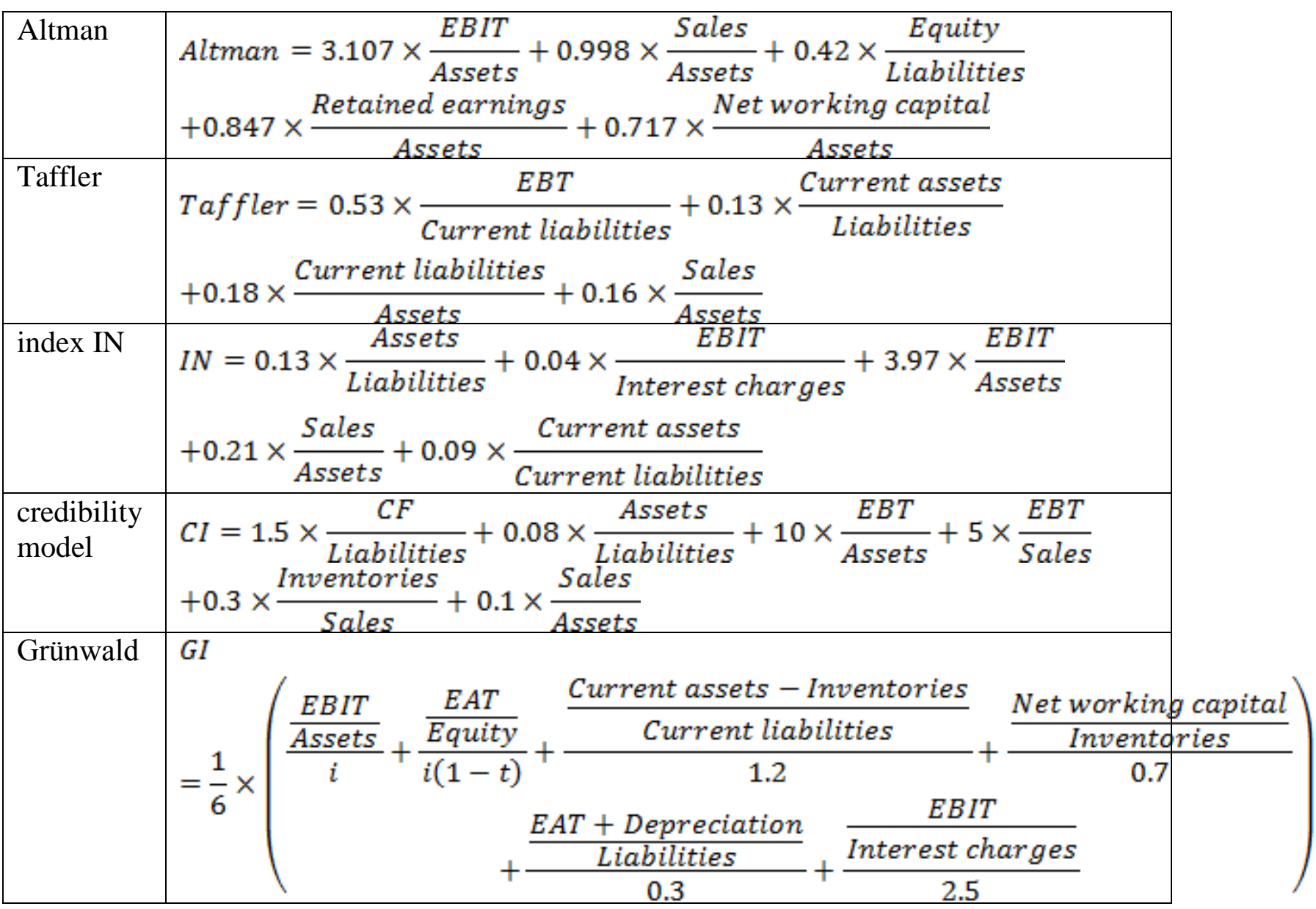

Interpretation:

\begin{tabular}{|l|l|l|l|l|l|}
\hline & Altman & Taffler & IN & Credibility & Grünwald \\
\hline bankrupting & $<1.2$ & $<0.2$ & $<0.9$ & $<-1$ & $<0.5$ \\
\hline prosperous & $>2.9$ & $>0.3$ & $>1.6$ & $>2$ & $>1.0$ \\
\hline
\end{tabular}

Kralicek's Quicktest:

\begin{tabular}{|l|l|}
\hline Indicator & Points \\
\hline Equity & $0.3^{+} \rightarrow 4 \mathrm{pts}$ \\
Assets & $0.2-0.3 \rightarrow 3 \mathrm{pts}$ \\
& $0.1-0.2 \rightarrow 2 \mathrm{pts}$ \\
& $0.0-0.1 \rightarrow 1 \mathrm{pts}$ \\
& $0.0^{-} \rightarrow 0 \mathrm{pts}$ \\
\hline Liabilities - Cash & $3 \rightarrow 4 \mathrm{pts}$ \\
\multicolumn{1}{|c|}{ Cash flow } & $3-5 \rightarrow 3 \mathrm{pts}$ \\
& $5-12 \rightarrow 2 \mathrm{pts}$ \\
& $12-30 \rightarrow 1 \mathrm{pts}$ \\
\hline EBIT & $30^{+} \rightarrow 0 \mathrm{pts}$ \\
\hline Assets & $0.15^{+} \rightarrow 4 \mathrm{pts}$ \\
& $0.12-0.15 \rightarrow 3 \mathrm{pts}$ \\
& $0.08-0.12 \rightarrow 2 \mathrm{pts}$ \\
& $0.00-0.08 \rightarrow 1 \mathrm{pts}$ \\
\hline
\end{tabular}




\begin{tabular}{|l|l|}
\hline Cash flow & $0.1^{+} \rightarrow 4 \mathrm{pts}$ \\
Sales & $0.08-0.1 \rightarrow 3 \mathrm{pts}$ \\
& $0.05-0.08 \rightarrow 2 \mathrm{pts}$ \\
& $0.00-0.05 \rightarrow 1 \mathrm{pts}$ \\
& $0.0^{-} \rightarrow 0 \mathrm{pts}$ \\
\hline \multirow{2}{*}{$Q T=\frac{\text { Points }}{4}$} & $>3$ prosperous company \\
\hline
\end{tabular}

